\title{
Editors' introduction to the Special Issue
}

\section{Changing realities, changing narratives? A narrative reading of EU perceptions in a changing Europe.}

\author{
PAULINE HEINRICHS \\ Royal Holloway, University of London, UK \\ pauline.heinrichs.2011@live.rhul.ac.uk \\ NATALIA CHABAN \\ University of Canterbury, New Zealand \\ natalia.chaban@canterbury.ac.nz
}

\author{
JAN OSIČKA \\ Masaryk University, Czech Republic \\ osicka@mail.muni.cz \\ VERONIKA ZAPLETALOVÁ \\ Masaryk University, Czech Republic \\ zapletalova@mail.muni.cz
}

\section{Introduction}

Studies of perceptions of the EU in post-Maidan Ukraine and post-Brexit Europe inevitably turn to the theme of a 'changing Europe in a changing world'. Our Special Issue makes a timely contribution to the question of how perception studies - as an approach to studying the EU - can help us understand narratives of change and continuity in and of Europe, some of which are paradoxical and some unexpected. Through this approach, we engage with strategic narrative theory (Miskimmon et al. 2013), which provides one explanation for how perceptions are shaped through and by information flows. Further, strategic narratives focus on how perceptions circulate between local, national and EU spaces in Europe, in relation to the past, present and future, and with which potential to mobilise audiences. We also consider synergies with other well-established theoretical models from political science scholarship, International Relations (IR) and European integration studies, and political communication studies. 
A conceptual intersection between strategic narratives and EU perception studies has already attracted scholarly attention (see Special Issue with European Security edited by Chaban, Miskimmon \& O'Loughlin, 2019; Chaban \& O'Loughlin, 2018). By adding to this emerging trend in the relevant literature innovatively, we bring a set of narrative forms tested through the empirical investigation of perceptions and narratives to the table: (1) Reluctant narratives; (2) Pragmatic narratives; (3) Nuanced narratives; (4) Generational narratives; and (5) Alternative narratives. The focus on narrative forms and their functions allows us to propose novel points to the theory of strategic narrative, but also to look at narrative scholarship more broadly.

Existing literature prioritises insights into external perceptions of the EU. The contributions to our Special Issue discuss change and continuity in narratives and narrative sensemaking within the EU - of events and key strategic moments for political actors in perceptions of and narratives on the EU. Academics, media and political commentators question resilience of the EU challenged by multiple crises. For some, the existence of the project is under existential threat. For others, the EU is more capable of responding to crises than other international actors (Moravcsik 2020). For yet another group, it is a about "à la cart Europe" - Europe at "different levels (variable geometry) or at different speeds" (multi-speed) (eur-lex, online). Understanding of narrative sensemaking inside evolving Europe may help us to answer our next question: Where and how strategic narratives about European integration are a means to make sense of perceived changes and new moments for different EU actors to engage? By answering these questions, we discuss changing narratives (sometimes rapidly) and contemplate potential rationales behind those changes (sometimes idealistic, sometimes accidental, and sometimes strategically pragmatic).

The articles in this Special Issue also keep in mind the complexity of the structure and interaction of strategic narrative with a variety of audiences, actors and "spheres". We seek to contribute to acknowledging and examining this complexity by asking: Where is the narrative on Europe produced in the European public sphere? As such, we add to the discussion on the role of narrators in the circulation of strategic narratives and stress that multiple narrators take part in the complex narrative cycle. While strategic narrative theory, originally an IR theory, often prioritises narrators on the state and elite level, we broaden the scope to reflect on the complexity. The contributions in the Special Issue look at actors within EU member states on the state level and at actors on the sub-state level (e.g. local/regional media, national parties), pan-European level (e.g. all-European parties) and supranational level (EU and its actors). The conceptualisation of the place and role of narrators in the lifecycle of strategic narratives is a scholarly gap (Chaban, Miskimmon \& O'Loughlin, 2019), which we seek to close further.

This introduction will first summarise the literature on narratives and strategic narratives to provide an overview of how the theoretical framework can shine a light on the difficulty with which the EU seeks to project its "actorness". By drawing on the meaningmaking potential of narratives, we further argue that the EU faces a multitude of challenges, not least in its efforts to align narratives of the Self and the perceived narratives by Others. We further discuss how a focus on narrative functions can be a way to approach (strategic) narratives in an innovative way, because it allows for an acknowledgement of the complexity inherent to narrative sensemaking, actors involved in the narrative cycle and levels of application. We subsequently turn to how (strategic) narrative can be operationalised and reflect on the multiple methodological approaches used by the authors in this Special Issue. A focus on methodology, such is the contention, 
can showcase the variety of methodological approaches and thus underlines the potential of narrative research to understand notions of change in the context of global uncertainty. This introductory article will lastly provide a brief summary of the individual contributions to the Special Issue.

\section{Theoretical frameworks and conceptual innovations}

Recent scholarship in IR has explored how the stories that agents tell - rather than broader conceptualisations of discourse - are decisive elements in the sensemaking and constitution of the political. For example, work on "strategic narratives" has linked the agency inherent to forging narratives and the strategic pursuit of objectives in IR (see Miskimmon, O'Loughlin \& Roselle, 2013; 2017). In this way, "analyzing strategic narratives in international affairs is central to our understanding of the forces that shape the world today" (Miskimmon 2017, p. 85).

Narratives are "discursive systems of meaning-making that are linked to the material world surrounding us" (Homolar \& Rodríguez-Merino, 2019, p. 563). As such, actors rely on narratives to make sense of the world and to incorporate experiences into coherent stories of the real world that would otherwise be incomprehensible. In this way, narratives structure reality in meaningful ways. In "emplotting" (White, 1997) and sequencing seemingly unconnected elements into coherent storylines, narratives provide the means to comprehend and order the complexity of the material world (see Barthes \& Duisit, 1975; Bruner, 1991; Fludernik, 2009; White, 1997).

The power inherent to how narratives can provide meaning and function as cognitive ordering devices, has been explored by the concept of "strategic narratives" (Miskimmon et al, 2013). Strategic narratives are "a means by which political actors attempt to construct a shared meaning of international politics to shape behavior of domestic and international actors" (Miskimmon, 2017, p. 88).

The existing literature has approached strategic narratives in a remarkably diverse manner. So far, it has been mainly preoccupied with identifying and interpreting emerging and established strategic narratives (Szostek, 2017, Bushell et al., 2017) or with discussing their acceptance by the target audience (Schmitt, 2018). The scholarship has also focused on issues such as building new strategic narratives around specific concepts (Kaldor et al., 2007) or challenges in contesting established ones (Kurowska, 2019).

When applied to the EU, the focus of our Special Issue, scholars have examined the narrative of the EU as a collective actor in many ways - the complexity of which is also evidenced by the many different roles the EU has been assigned. Concepts such as "normative power" (Manners, 2002), "social power" (van Ham, 2010), and "ethical power" (Aggestam, 2008) all speak to different narratives underpinning the narrative cycle of formation, projection and reception (Miskimmon, O'Loughlin and Roselle, 2013) in the study of the EU's narrative sensemaking. Similarly, the EU has invested considerable efforts in projecting a coherent storyline of itself as an actor. Yet, "the EU strategic narrative is complicated by the hybrid nature of the institution - reflecting both supranational and intergovernmental aspects, which frustrates efforts to speak with a single European voice in international affairs" (Miskimmon, 2017, p. 85). The difficulty in providing a coherent identity narrative that can be projected into the international arena also "hamper[s] the EU's strategic impact" (Miskimmon, 2017; see also Murray \& Manners, 2017, on EU narratives and their challenges). In an international environment 
that is marked by crises, uncertainties and indeed, changes, the lack of coherency in the EU's strategic narrative has important implications also for how other actors engage and interact with the EU as an international actor.

The study of perceptions speaks to these contestations and examines the effects of such confusion over what the EU 'is' as an international actor. For example, relevant works in the field of EU perceptions suggest that the EU as an international actor is perceived in many different ways by external actors, and oftentimes in contrast to what the EU seeks to project in the first place (Chaban \& Elgström, 2014; 2020; 2021a, b). The scholarship argues that the perception of the EU is contingent on the interaction of EU-, location-, region-specific factors, as well as global factors (Tsuruoka 2008; Chaban \& Magdalena, 2014; Chaban et al., 2020). They are also dependent on systemic, national and individual factors (Chaban, Knodt \& Headley 2018) and tend to be affected by long-, middle- and short-term historical distances (Didelon-Louisau \& Grasland, 2014; Chaban, 2020). These findings are not only crucial to understanding perceptions of the EU outside of the EU but also within it. Where an understanding of strategic narratives is difficult given the complex institutional nature of the EU, so is an understanding of how these narratives are perceived and how other actors, on multiple levels interact and reciprocate these narratives. This Special Issue seeks to examine how other actors draw on strategic narratives of the EU to make sense of the Self. We argue that this level of disaggregation is necessary, where the scholarship still struggles with how to assess the reception of narratives (see Miskimmon \& O’Loughlin 2019).

Further, given the EU's multiple crises both externally and internally, strategic narratives and their perception are a crucial element to understanding the new pressures created by the changing reality that the EU interacts with. While, as argued, many different narratives have pointed to different concepts and notions worth investigating, we seek to contribute to the existing scholarship by looking at the function of narratives within the context of perception. We, therefore, contribute to the rich discussions in the field by testing a set of narrative functions in the context of the changing realities, and ultimately, uncertainties the EU is facing and will have to tackle if it is to carry a coherent narrative of the Self through time. The functional narratives tested through the empirical investigations in this special volume are:

\section{Reluctant narratives}

We identify reluctant narratives as means of negotiating between different normative strands that make sense of contrasting narratives by imposing system uncertainties and conditions on processes of narrative sensemaking. Reluctant narratives speak to these uncertainties and weave these into the objectives negotiated in processes of narrative sensemaking. Narratives serve to outline avenues of compromise and, further, seek to make sense of inhibitions and reluctant policy behaviour in the attempt to justify reluctance to other actors or the context from which they emerge. In this Special Issue, Maili Vilson dissects reluctant Europeanisation narrative in the case of Estonia's negotiation of different internal ideological positions on the EU's Green Deal.

\section{Pragmatic narratives}

Pragmatic narratives are sensemaking devices that give priority to the rationality and pragmatism of policy preferences where the achievement of objectives is contingent. Pragmatic narratives seek to negotiate crises by seemingly driving narrative 
sensemaking away from an ideology-based narrative negotiation towards a rational interaction between and with actors. Pragmatic narratives further serve to withdraw from the broad - and rather commonly accepted - understanding of the EU in terms of its normative appeal towards what actors can bring to and take from the "table" of advantages and disadvantages that the EU brings. Our Special Issue shows the prominence of pragmatic narratives in narratives on the EU, for example, as highlighted in the context of the EU's Green Deal, in Estonia (Vilson in this Special Issue) and Latvia (Kleinberga in this Special Issue).

\section{Nuanced narratives}

Nuanced narratives seek to make sense of and emphasise the inherently complex nature of EU narratives and their interaction on multiple levels. As such they seek to disaggregate "black and white" approaches by placing nuances and contextual differences at the heart of narrative sensemaking. Instead of seeking to brush over inconsistencies of the Self, they seek to make sense of the Self in acknowledgement and embrace of inconsistencies. Nuanced narratives occur less frequently in the contributions made to this Special Issue but do have a place in the negotiation of crises and the EU's future (see Heinrichs in this Special Issue), but also in the construction of European public spheres through local media (see Pluschke in this Special Issue).

\section{Generational narratives}

Generational narratives are a means to narrate change to identity narratives at the same time at which they speak to different experiences of different generations. Generations are, in one way, narratives themselves. In this way, the production of generational narratives can be seen as a way to enact and substantiate generations. Generational narrative are essentially tools to narrate and to make sense of perceived (and potentially striking) changes in new realities. Generational narratives matter specifically for a negotiation of future narratives such as the EU's more recent COVID-19 responses as explored by Heinrichs.

\section{Alternative narratives}

Alternative narratives are sensemaking devices that take either given narrative structures or contexts and juxtapose these to alternative readings. They rely on outlining why a given narrative structure is flawed and why the alternative takes priority over and makes better sense of a given reality. Alternative narratives can be used in a variety of ways and related to different narrations of temporality, for example by offering alternative readings of history or by offering alternative suggestions for an envisaged future. Alternative narratives are particularly visible in Popivanov's exploration of how the far-right seeks to (spatially and) narratively construct an "other Europe", thereby strategically seeking to delegitimise the EU's effort to project a coherent narrative of the Self. Deimantaitè's paper speaks to similar efforts, when examining how actors create and forge new narratives of EU sovereignty, at a time where the "unitary actorness" of the EU is not entirely clear.

Crucially, all these narratives and their potential functions in understanding perceptions of the EU interact. They can be strategically used in a variety of ways to achieve a variety of objectives. In this way, the Special Issue seeks to embrace the highly complex, interrelated and disaggregate nature of strategic narrative processes, especially where 
they seek to make sense of a highly complex institution such as the EU. We focus in particular on narratives as means to achieve certain outcomes, i.e. their strategic potential and their strategic function.

\section{Overview of the methods}

Methodologically, strategic narrative studies typically build on qualitative content analysis (Anderson, 2015; Natarjan, 2014), but scholars also employ more targeted approaches such as critical discourse analysis or metaphor analysis (see Hellman \& Wagnsson, 2013; Xin \& Matheson, 2018). More significant variation can be found in data collection and processing techniques. While some studies make their approach explicit (Anderson, 2015), many opt for the "reading and interpreting" approach (Schmitt, 2018) or avoid discussing the nature of the process at all (Kaldor, Martin, \& Selchow, 2007; Bushell et al., 2017). This Special Issue reflects the methodological diversity surrounding the concept. While drawing mainly from qualitative content analysis, its contributors also employ frame analysis, quantitative content analysis (Vilson in this Special Issue) or critical discourse analysis (Popivanov in this Special Issue). This diversity allows for communicating the use of various approaches in a more detailed manner which provides a better guidance for the reader and fosters reliability of the presented studies. It follows that the SI showcases a range of methods to study perceptions and narratives and tap into a range of discourses - media, official, party, all of which are important for the European public sphere - and especially, at times of change and crises.

\section{Structure and the key findings of the Special Issue}

Each contribution in this Special Issue offers a distinct perspective on change, continuity and crises and how actors negotiate the context and content of narrative sensemaking:

By looking ahead and towards the negotiation of EU futures during the initial months of the COVID-19 pandemic by the - then newly elected - EU Commission, Pauline Heinrichs initiates this Special Issue by arguing that The Strategic Negotiation of Future Identity During Times of Crises, is a means to forge and negotiate identity narrative commitments around visions for future pathways. Times of crises serve as a means to credibly enable actors to push for narrative redescriptions. Heinrichs finds, however, the navigating uncertainty in times of crises without offering a clear vision for future identity commitments can leave such negotiation processes void. Her paper offers an innovative theoretical link between strategic narrative theory and ontological security in IR to examine how actors can deploy agency during times of crisis.

Maili Vilson's article Recent Trends in Elite Perceptions of the European Union in Estonia: A Balancing Act discusses how the Estonian government framed the EU during its first year in office, especially since the new government involving the populist EKRE party has produced a complex environment for Estonia's Europeanisation narrative. The EU's Green Deal offers a means to negotiate different ideological positions towards a pragmatic and reluctant Europeanisation narrative.

Vineta Kleinberga's contribution The European Narrative in Latvia: The Case of the Climate Change Mitigation resonates with Vilson's research, examining how Latvia deals with the change brought about by a changing climate and the EU's policy response to it. In rebranding itself as an 'active promoter' of carbon neutrality, Latvia has found a way 
to embrace change as a means to 'rebranding' its identity and to position Latvia as a reliable and progressive partner.

While climate change policy is a means to rebrand the Latvian identity narrative Aiste Deimantaite examines Problems and Transformations of the Concept of Sovereignty in the Politics of the European States and the European Union: The Case of Lithuania. Far from simply a question of how much scope for sovereignty different narratives of the EU's future trajectory offer, Deimantaitè concludes that the inherent difference in narrating sovereignty is a means for actors to tackle, challenge or forge European identity.

While challenging or embracing European identity in the context of solidarity points to different strategic uses of narrative sensemaking, Muriel Pluschke zooms in on Europe in the Local and how local newspapers contribute to the making of European public spheres. The constitution of European public spheres is a crucial element for the possibility of narrative identification. By examining the possibility of how such identification is institutionalised through structures of a European public sphere, Pluschke seeks to elaborate how local newspapers present a microcosm for cross-border narrative sensemaking.

In closing our Special Issue and the temporal circle to Heinrichs' paper, Boris Popivanov discusses Visions of Europe and Self-Images of the Populist Right: Dis-Continuities with the Past. In doing so, he focuses in particular on the temporal and spatial representations of Europe and argues that the radical right managed to construct a relatively coherent image of the EU as a distant undemocratic actor in sharp contrast to the alternative narrative of one 'Europe of fatherlands' described in mostly civilisational terms.

\section{Concluding remarks}

It follows that much lies ahead for the EU and that the complexity of EU perceptions inside and outside the Union has been accelerated by the changing realities the EU faces and interacts with. Ultimately, and while focused on narrative and perception of the EU from within the Union, our Special Issue tackles big concepts, such as sovereignty, solidarity, nationalism, the public sphere, democracy and agency. To be sure, the contributions to such 'big-ticket' concepts can only be modest, yet they indicate how strategic narrative research can provide new insights into core notions of different research areas. Lastly, our Special Issue seeks to engage with new and exciting possibilities to understand the changing realities of our times; a task that calls for creativity, innovation and new perspectives in researching the EU and its perception.

\section{Acknowledgement of support}

Our team of co-editors and contributors would like to acknowledge the generous support of the COST Action EU Foreign Policy Facing New Directions (ENTER) (2018-2021) funded by the European Commission. The Action brought all of us together within the framework of the COST ENTER Winter School "Images of Europe at Times of Global Challenges: Perceptions of EU (foreign) policy making inside and outside Europe Theoretical, Methodological and Empirical Reflections" at the University of Aarhus, Denmark, from 11 to 14 November 2019, and once again in a two-day COST International Virtual Symposium "Narratives and perceptions of the EU: Images of the EU in the EU" in June 2020. 


\section{References}

Aggestam, L. (2008). Introduction: ethical power Europe?. International Affairs, 84(1), 1-11.

Anderson, L.B. (2015). Changing the story of retirement: How AARP utilizes a strategic narrative to advocate for the aging workforce". Public Relations Review, 41(3).

Barthes, R. \& Duisit, L. (1975). An Introduction to the Structural Analysis of Narrative. New Literary History, 6(2), 237-272.

Bruner, J. (1991). The Narrative Construction of Reality, Critical Inquiry, 18, 1-21.

Bushell, S., Satre Buisson, G., Workman, G.S., \& Colley, T. (2017). Strategic narratives in climate change: Towards a unifying narrative to address the action gap on climate change, Energy Research \& Social Science, 28, 39-49.

Chaban, N. (2020) Perceptions, expectations, motivations: Evolution of Canadian views on the EU'. Australian and New Zealand Journal of European Studies, 11(3), 45-62.

Chaban, N., \& Elgström, O. (2020). A Perceptual Approach to EU Public Diplomacy: Investigating Collaborative Diplomacy in EU-Ukraine Relations, The Hague Journal of Diplomacy, 15(4).

Chaban, N., \& Elgström, O. (2021). Theorizing External Perceptions of the EU, in S. Gstöhl and Schunz (eds.), Studying the EU's external action: concepts, approaches, theories, Palgrave, forthcoming.

Chaban, N., \& Elgström, O. (2021, forthcoming). Politicization of EU development policy: The role of EU external perceptions (case of Ukraine), Journal of Common Market Studies.

Chaban, N., Elgström, O., Kelly, S., \& Lai, S.-Y. (2013). Images of the EU beyond its borders: Issue-specific and regional perceptions of EU power and leadership, Journal of Common Market Studies, 51(3), 433-451.

Chaban, N., Knodt, M. \& Headley, J. (eds.) (2018). Special Issue "The EU and its Eastern Neighbours: Perceptions and Strategic Dialogue in the Region”, Special Issue European Foreign Affairs Review, 23(1/1).

Chaban N. \& Magdalena, A.-M. (2014). External perceptions of the EU during the Eurozone Sovereign Debt Crisis. European Foreign Affairs Review, 19(2), 195220.

Chaban, N., Miskimmon, A. \& O'Loughlin, B. (2019). Strategic Narratives and Perceptions of the EU in Ukraine, Israel and Palestine. European Security, 28(3), 235-250.

Chaban, N., Miskimmon, A. \& O'Loughlin, B. (eds) (2019). Understanding the scope and limits of EU diplomacy - Connecting strategic narrative to EU external perceptions research, Special Issue European Security, 28(3). 
Chaban, N., \& O'Loughlin, B. (2018). The EU's Crisis Diplomacy in Ukraine: The Matrix of Possibilities, Journal of International Affairs, 71(1.5).

Chaban, N., Niemann, A., \& Speyer, N. J. (eds.) (2020). Changing perceptions of the EU at times of Brexit: Global Perspectives, Abington and NY: Routledge.

Didelon-Loiseau, C. \& Grasland, C. (2014). Internal and External Perceptions of Europe/the EU in the World through Mental Maps. In N. Chaban and M. Holland, Communicating Europe in Times of Crisis: External Perceptions of the European Union (pp. 64-95). Houndmills: Palgrave Macmillan.

Eur-Lex, https://eur-lex.europa.eu/summary/glossary/europe a la carte.html.

Fludernik, M. (2009). An Introduction to Narratology. London and New York: Routledge.

Hellman, M. \& Wagnsson, Ch. (2013). New Media and the War in Afghanistan The Significance of Blogging for the Swedish Strategic Narrative, New Media \& Society, 17(1), 6-23.

Homolar, A. \& Rodríguez-Merino, P.A. (2019). Making Sense of Terrorism: A Narrative Approach to the Study of Violent Events. Critical Studies on Terrorism, 12(4), 561581.

Kaldor, M., Martin, M., \& Selchow, S. (2007). Human Security: A New Strategic Narrative for Europe. International Affairs, 83(2), 273 - 288.

Kurowska, X. (2019). The politics of cyber norms: Beyond norm construction towards strategic narrative contestation. EU Cyber Direct. Retrieved from: https://eucyberdirect.eu/wp-content/uploads/2019/05/xymenakurowska-politics-of-cyber-norms-march-2019-eucyberdirect.pdf

Manners, I. (2002). Normative power Europe: A contradiction in terms? Journal of Common Market Studies 40(2). 235-258.

Miskimmon, A. (2017). Finding a Unified Voice? The European Union through a Strategic Narrative Lens. In A. Miskimmon, B. O'Loughlin \& L. Roselle (Eds.). Forging the World. Strategic Narratives and International Relations. Ann Arbor: University of Michigan Press (pp. 85-109).

Miskimmon, A., \& O'Loughlin, B. (2019). Narratives of the EU in Israel/Palestine: narrative "stickiness" and the formation of expectations. European security, 28(3), 268-283.

Miskimmon, A., O’Loughlin, B. and Roselle, L. (2013). Strategic Narratives: Communication Power and the New World Order. New York: Routledge.

Miskimmon, A., O'Loughlin, B., \& Roselle, L. (2017). (eds.) Forging the world: Strategic narratives and international relations. Ann Arbor: University of Michigan Press.

Moravcsik, A. (2020) Why the EU Wins. Foreign Affairs, Fall 2020, 238, 46-52. 
Manners, I. \& P. Murray (2016) The End of a Noble Narrative? European Integration Narratives after the Nobel Peace Prize. Journal of Common Market Studies, 54, 185-202.

Natarajan, K. (2014). Digital public diplomacy and a strategic narrative for India. Strategic Analysis, 38(1), 91-106.

Schmitt, O. (2018) When are strategic narratives effective? The shaping of political discourse through the interaction between political myths and strategic narratives. Contemporary Security Policy, 39(4), 487-511.

Szostek, J. (2017) The Power and Limits of Russia's Strategic Narrative in Ukraine: The Role of Linkage. Perspective on Politics, 15(2), 379-395.

Tsuruoka, Michito. 2006. How external perspectives of the European Union are shaped: Endogenous and exogenous sources, paper prepared for the 2oth World Congress of the International Political Science Association (IPSA), Fukuoka, Japan, 9-13 July.

van Ham, P. (2010). Social Power in International Politics. New York: Routledge.

White, H. (1997). 'Historical Emplotment and the Problem of Truth.' In: Keith Jenkins (ed.). The Postmodern History Reader. London and New York: Routledge (pp. 392-396).

Xin, J. \& Matheson, D. (2018). One Belt, Competing Metaphors: The Struggle Over Strategic Narrative in English-Language News Media. International Journal of Communication, 12, 4248-4268. 